N. M. Kononenko, A. M. SheikhaLi

National University of Pharmacy

\title{
THE STUDY OF REPARATIVE PROPERTIES OF A NEW COMBINED CREAM DERMALIPOIN ON THE MODEL OF LINEAR INCISED WOUNDS
}

In the topical treatment of inflammatory skin diseases promising are herbal medicinal products. A new combined drug in a form of cream for treatment of skin inflammatory and germ diseases, tentatively named "Dermalipoin", which consists of: $\alpha$-lipoic acid, urea, olive oil, tea tree oil, PEG-400 was studied in model turpentine dermatitis in rats. The efficiency of the cream "Dermalipoin" was estimated after the general amount of leucocytes, peripheral blood leukocyte composition, thickness of skin folds and skin. Based on the study, it was shown that the cream "Dermalipoin" has a pronounced anti-inflammatory effect and is more active drug compared to the ointment "Fladeks".

Key words: $\alpha$-lipoic acid; urea; olive oil; tea tree oil; PEG-400; turpentine dermatitis

\section{INTRODUCTION}

The problem of regeneration of wounds of varied etiology continues to be of great current interest. It is associated with numerous home and industrial accidents, natural disasters, transport accidents as well as with the increase of number of surgical infectious diseases and postsurgical complications. According to statistical data, the frequency of wound infectious complications in surgery measures up to $30 \%$, in combustiology $-40 \%$, and in dermatology - $7 \%$. One of solutions of this problem is the application of medical drugs for stimulation of reparative processes and approach of reparative regeneration to physiological one. Topical application of mild medical products, which would have multitargeted action and could be applied depending on phase of wound process, is required for wound treatment. So, the drugs which are applied in I-II phases of wound process shall have hydrophilic bases with moderate dehydrate potency, provide anti-inflammatory reparative potency and protect against superimposed infection. However, many modern medical products have a range of disadvantages: narrow spectrum of specific action, poor efficiency, as well as side effects, in particular, hypersensitivity reactions which mainly manifest themselves as edema, dermatitis, irritation of tissues, skin itch, etc.

For this reason, the search for high-efficiency medical products for wound and burn treatment is topical problem of modern surgery, combustiology and dermatology.

A new combined drug in a form of cream for treatment of skin inflammatory and germ diseases, tentatively named "Dermalipoin", which consists of: $\alpha$-lipoic acid, urea,

(c) Kononenko N. M., Sheikhali A. M., 2016 olive oil, tea tree oil, PEG-400, was developed in the National University of Pharmacy. $\alpha$-lipoic acid is a coenzyme of carboxylase group and has florid anti-oxidant action. It was testified that many antioxidants possess anti-inflammatory properties both on internal and external application. Olive oil possesses anesthetic, reparative and anti-inflammatory properties. Tea tree oil is a very strong antiseptic (8 times stronger than carbolic acid and 12 times stronger than phenol); it also has florid anti-bacterial, antifungal, antiviral and immunostimulating actions. PEG-400 is a solvent with florid osmotic potency which determines its widespread application in production of creams for treatment of infected wounds where it provides osmotic and dehydrating action which, in its turn, accelerates the period of wound repair $[1,5]$.

The goal of the study was to investigate reparative properties of the cream on the model of linear incised wounds.

\section{MATERIALS AND METHODS}

Experiment was conducted on 40 non-pedigree male rats of $200 \pm 20 \mathrm{~g}$ in weight, which were divided into 4 groups: I - animals with wounds without treatment (control pathology); II - rats with wounds treated with cream "Dermalipoin", III - rats with wounds treated with comparator drug - cream "Carboderm" produced by "FF"Darnica” (Ukraine), group IV - animals with wounds treated with comparator drug gel "Titriolum" produced by OST-Farm LLC (Ukraine).

An incision of $5 \mathrm{~cm}$ in length up to own fascia was aseptically made on animals dehaired skin area of $5 \times 3 \mathrm{~cm}^{2}$ under anesthesia for simulation of linear wound. 5 stitches at a distance of $1 \mathrm{~cm}$ from each other were put and skin was debrided with $5 \%$ alcohol-based iodine at once. 

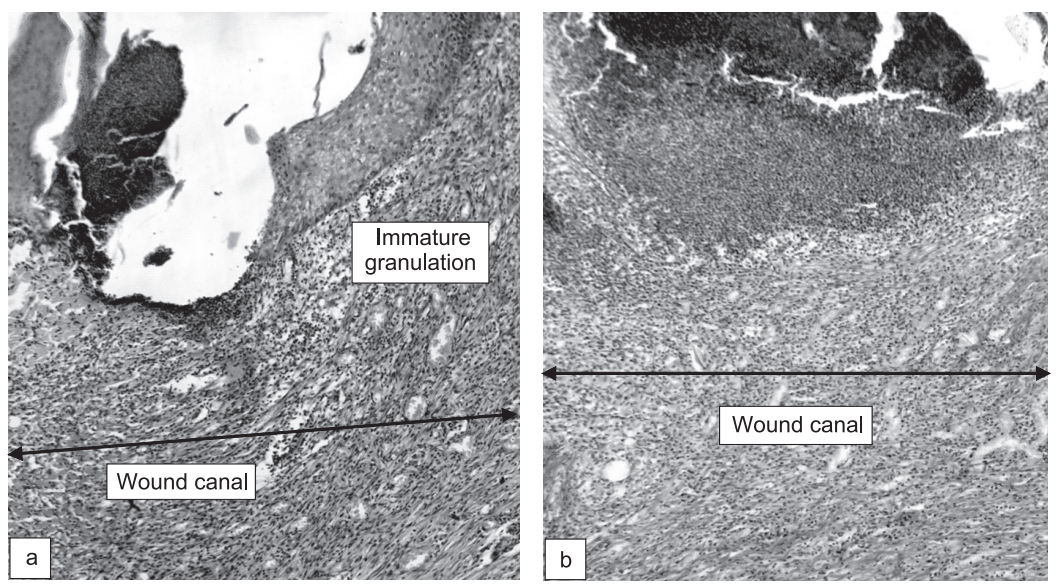

Fig. 1. Stitched-up linear incised wound of control rats. Remain of fibro-purulent crust on the surface of a wide wound canal, granulation tissue which fills the canal is rather immature (a, haematoxylin-eosin), poor evidence of fiberization (b, Picro-fuchsin according to the method of van Gieson). x100

Next day the 5-day treatment started. On the seventh day of experiment the animals were decapitated and skin with cicatrix and unaffected skin areas contiguous to this skin was cut off.

All samples were fixed in $10 \%$ formalin solution, desiccated in alcohols of increasing concentration, embedded in celloidin-paraffin. Slices of 3-5 $\mu \mathrm{m}$ in thickness were stained with haematoxylin and eosin, with picro-fuchsin according to the method of van Gieson (stain of collagen fibers in a newly-formed tissue) [2, 8]. Microslides were viewed by the light microscope Granum, photographs of microscope images were taken by digital video camera Granum DSM 310. Photographs were computerized by Pentium 2.4 GHz with the help of program Toup View.

For added convenience of comparative estimation of results obtained on slices, semi-quantitative (point-based) appraisal of wound canal, condition of newly-formed tissue in it (evidence of vascularization, proliferation of fibroblasts, fiberization), completeness of skin restoration in the area of healed wound was conducted. Semiquantitative method of visual estimation of Sokolovskii was taken as a basis [6, 7]. The following scheme was used:

\section{Width of wound canal:}

0 points - wound canal is in a form of very narrow strip; 1 point - wound canal is in a form of thin band;

2 points - wound canal occupies $1 / 3$ of microscope field;

3 points - wound canal occupies $1 / 2$ of microscope field;

4 points - wound canal occupies $2 / 3$ and more of microscope field.

\section{Maturity of newly-formed tissue:}

0 points - newly-formed tissue is very densely-celled. Lymphocytes, neutrophilic leucocytes, macrophages prevail. Newly-formed blood vessels are singular. Fibroblasts are single, collagen fibers are absent (immature granulation tissue);

1 point - cell component of tissue is significant, macrophages prevail, newly-formed vessels are mainly of "bottom" disposition. Fibroblasts are rare, immature and dis- posed at random. Collagen fibers are single, poorly fuchsinophil, positioned in the bottom or along the edges of the wound (poorly mature granulation tissue);

2 points - vascularization is diffuse, fibroblasts prevail. Collagen fibers are thin, disposed at random, fuchsinophily ranges from moderate to significant (moderately mature granulation tissue);

3 points - transformation of granulation tissue into loose fibrous tissue with varied content of blood vessels and cell bulk;

4 points - almost zero defect.

3. Completeness of skin restoration in the area of former wound:

0 points - symptom is absent;

1 point - regenerated epithelial sheet with typical differentiation of layers, but abnormal epithelization, degeneration of epidermal cells, cornification disturbance can take place. Bundle texture, typical for derma, is absent in collagen component of tissue, derma appendages are absent;

2 points - regenerated epithelium is of normal form, collagen tissue structures obtain texture, typical for derma, derma appendages are absent;

3 points - epidermis, derma and derma appendages are restored.

Statistical processing of results was carried out using non-parametric analogue of One-Way ANOVA - KruskalWallis test, after which Mann-Whitney test was used [2-4]. For the aim of determining of statistic discrepancies standard programs suite "Statistica 6" was used.

\section{RESULTS AND DISCUSSION}

According to review microscopy, wound canal of $75 \%$ of rats of control pathology group is rather wide and deep, sometimes covered with crust which was easily flaked off. Epithelial sheet did not cover the central part of the canal, distinctively thickened on each side, often with acanthosis symptoms, sometimes with symptoms of parake- 

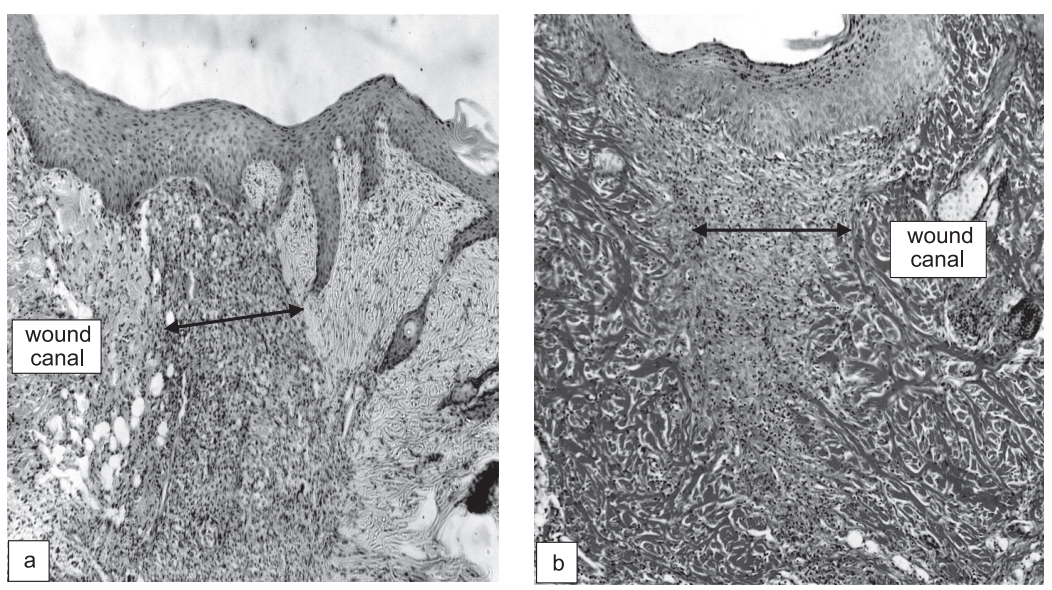

Fig. 2. Stitched-up linear incised wound of control rats. Wound canal is moderate across the width, newly-formed tissue contains reduced vessels ( $a$, haematoxylin-eosin), thin, not fasciculated in bundles and moderately fuchsinophil collagen fibers (b, Picro-fuchsin according to the method of van Gieson). x100

ratosis, perinuclear edema. In some cases, rather big internal epidermal corneal plugs can be seen. Canal is filled with granulation tissue of varied maturity degree. In epilayers it was densely-celled - it contained neutrophilic leucocytes, lymphocytes, poorly differentiated fibroblasts, it was poorly vascularized. Collagen fibers were slightly determined. Lymphocytes and fibroblasts of varied maturity degree prevailed; vascularization was more significant in cell content of deeper canal areas. Collagen fibers were mainly thin, short, not fasciculated in bundles, poorly fuchsinophil, disposed at random, determined in bottom areas and along the edges of wound canal (Fig. 1).

Wound canal of $25 \%$ of animals is moderate across the width, completely covered with thickened epidermis sheet, filled with newly-formed tissue, which contains moderate quantity of lymphocytes and fibroblasts, blood vessels are absent. Collagen fibers are thin, poorly fuchsinophil, not fasciculated in bundles. Restoration of skin appendages is absent (Fig. 2).

Inflammation symptoms (here and there - small spots of purulence) can be seen in subcutaneous tissue under wound canal as well as on each side of it, on some spots it is replaced by fibrous tissue. Inflammatory reaction was also observed in muscle plate (Fig. 3).

On application of cream "Dermalipoin", complete wound repair was observed on the skin of all rats. Former wound canal of $83.3 \%$ of animals looked like a very narrow strip, on each side of which a restored derma with hair follicles and oil glands connected with them can be observed. Epidermis in the area of former wound and in areas contiguous to this wound is thickened, but all layers are completely renewed including corneal one. Sometimes remains of thin crust are observed on the surface of the skin. Residual symptoms of inflammatory reaction can be seen in subcutaneous tissue (Fig. 4). Restoration of normal bundling of derma collagen fibers in the area of former wound is clearly observed while van Gieson stain with picro-fuchsin, fibers with significant fuchsinophily is even observed in the band area between cells (Fig. 5).

Wound canal of $16.7 \%$ of rats was not visible, but a completely epithelized wide fibrous cicatrix was detected at its place. Collagen fibers are highly fuchsinophil, fas-
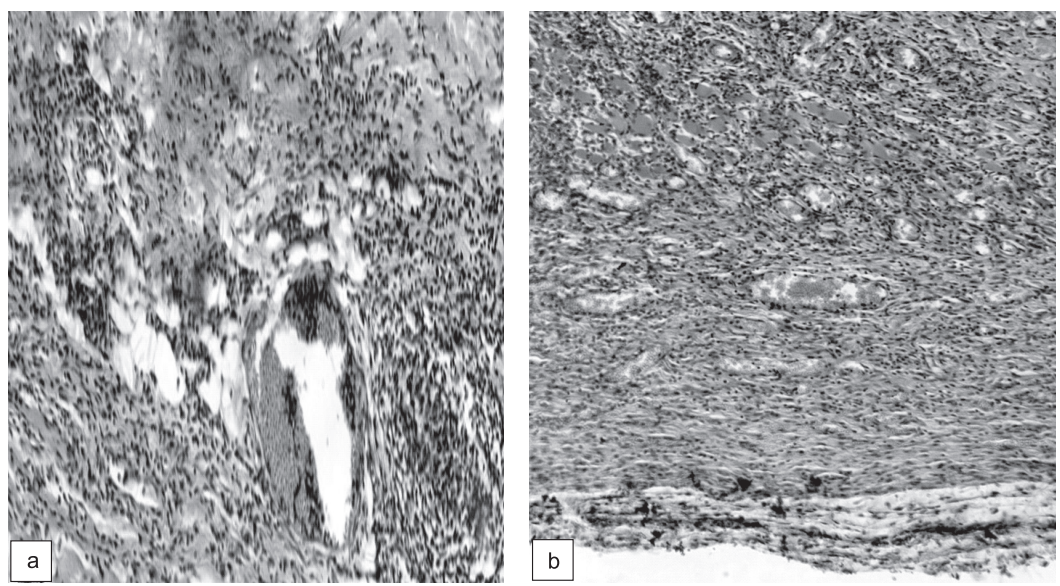

Fig. 3. Tissues under stitched-up linear incised wound of control rats: a - inflammatory reaction in subcutaneous tissue; $b$-inflammation in muscle plate, replacement of subcutaneous tissue by fibrous tissue. Haematoxylin-eosin. x100 

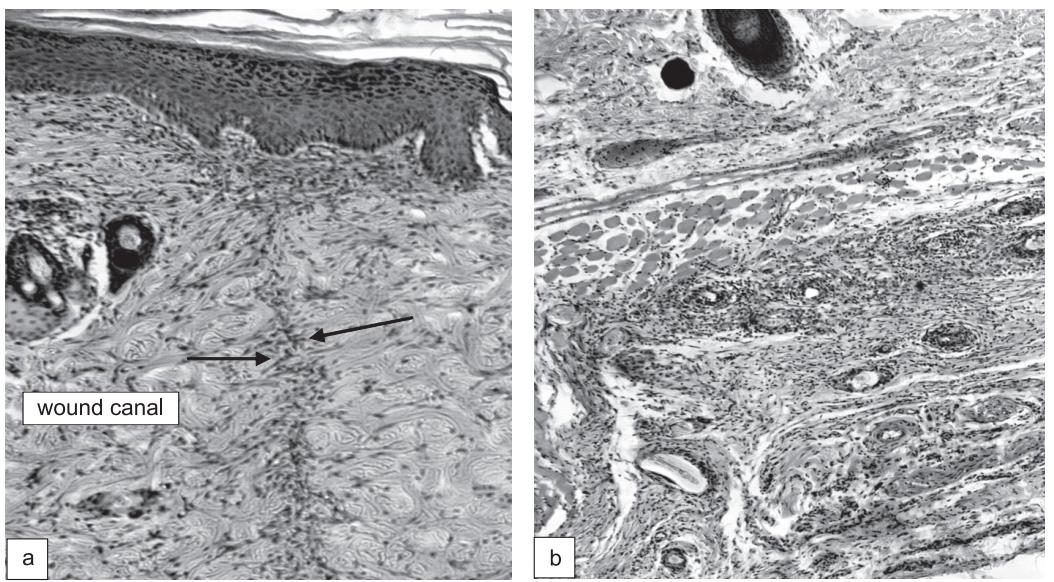

Fig. 4. Stitched-up linear incised wound of rats' skin which was treated with cream "Dermalipoin": a - complete repair, former wound canal looks like a very narrow strip (x200); b-residual symptoms of inflammation in subcutaneous tissue (x100). Haematoxylin-eosin
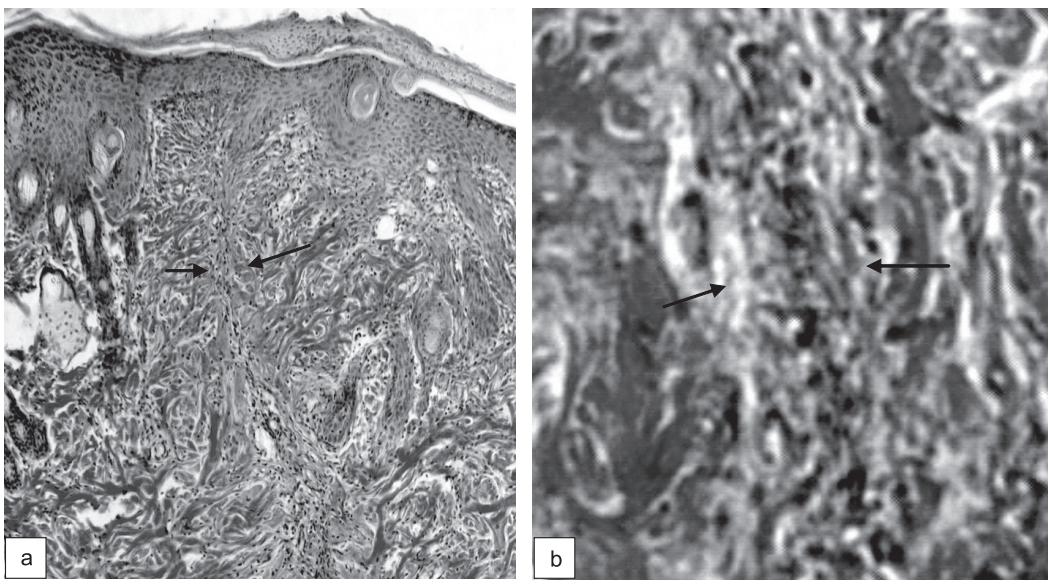

Fig. 5. Stitched-up linear incised wound of rats'skin which was treated with cream No. 1: a - complete restoration of derma collagen matrix around a very narrow strip in the area of former wound canal (x100); $b-$ significant fuchsinophily among strip cells (x400). Picro-fuchsin according to the method of van Gieson

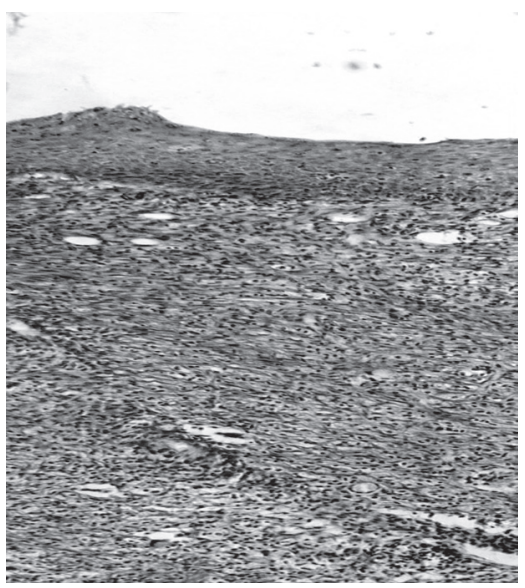

Fig. 6. Stitched-up linear incised wound of rat's skin which was treated with cream "Dermalipoin".

Fibrous epithelized cicatrix in the area

of former wound. Picro-fuchsin according

to the method of van Gieson. x100 ciculated in oriented bundles. Restoration of skin appendages is absent (Fig. 6).

After treatment with cream "Carboderm", width of wound canal of $80 \%$ of rats is still significant, central part is not epithelized. There are remains of cell debris on the surface. Newly-formed tissue which filled the canal is properly vascularized, it is still densely-celled in epilayers. Proliferation of fibroblasts, with orientation in disposition here and there, presence of thin collagen fibers are observed in deeper layers. Clear symptoms of productive inflammation are observed in muscle plate and subcutaneous tissue (Fig. 7). The remaining $20 \%$ of animals have complete epithelization of wound canal under crust the width of which is significantly reduced. Epidermis is thickened, definitive layers are clearly observed in it. Blood vessels in newly-formed tissue which has filled the wound are practically reduced, diffuse fiberization is observed. Collagen fibers are thin, rather highly fuchsinophil, though they are not fasciculated in bundles typical for normal derma. Restoration of skin ap- 

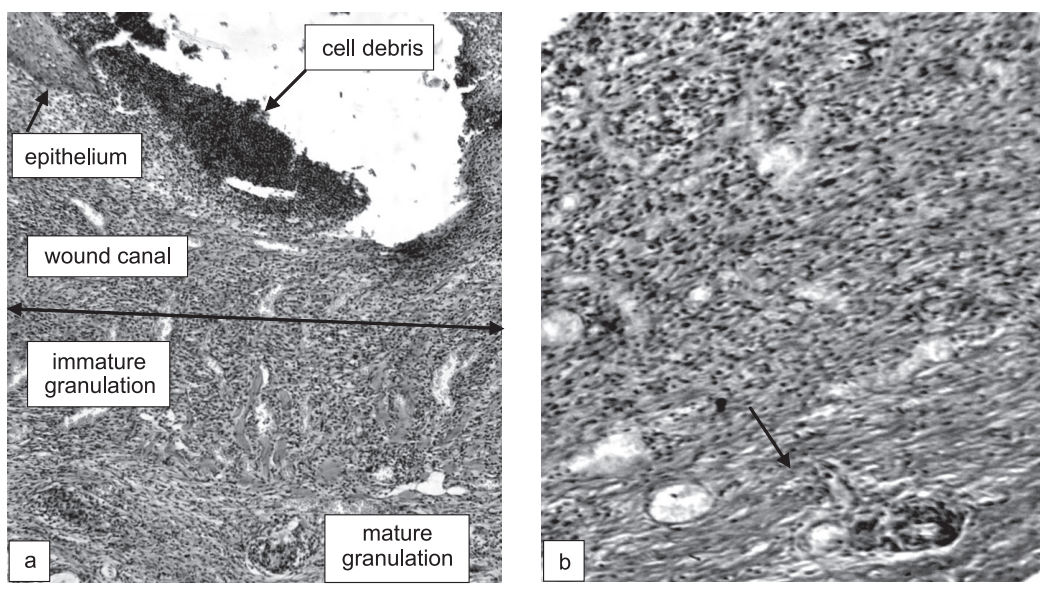

Fig. 7. Stitched-up linear incised wound of rats' skin which was treated with cream "Carboderm": a - wound canal is wide, epithelization is not complete, there is a debris on the surface, there is a significant vascularization and cell component of granulations (haematoxylin and eosin); $b$ - significant fiberization in bottom area (Picro-fuchsin according to the method of van Gieson). x100
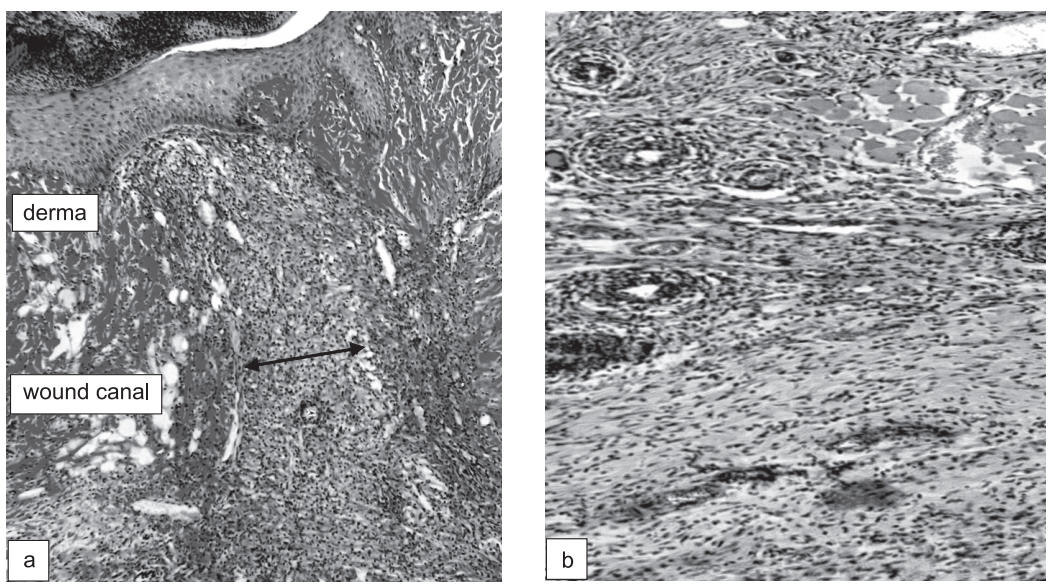

Fig. 8. Stitched-up linear incised wound of rats' skin which was treated with cream "Carboderm": a-properly fuchsinophil collagen fibers of newly-formed tissue (Picro-fuchsin according to the method of van Gieson);

$b$ - fibrous tissue replaces muscle plate and subcutaneous tissue (haematoxylin and eosin). x100
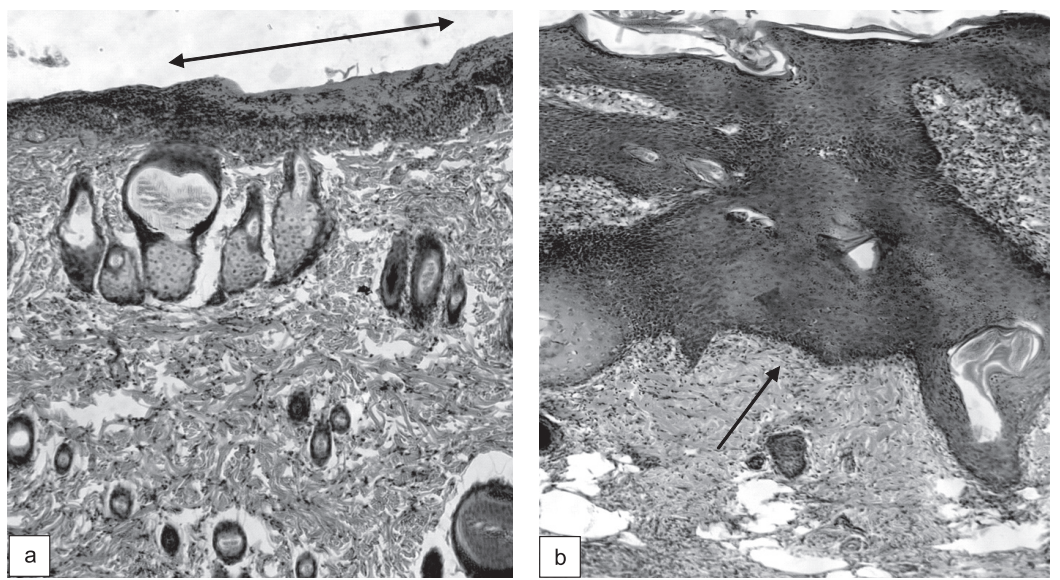

Fig. 9. Rats' skin area out of wound which was treated with cream "Carboderm": a - "erosive" skin lesion; $b$ - significant acanthotic epidermis proliferation. Haematoxylin and eosin. x100 

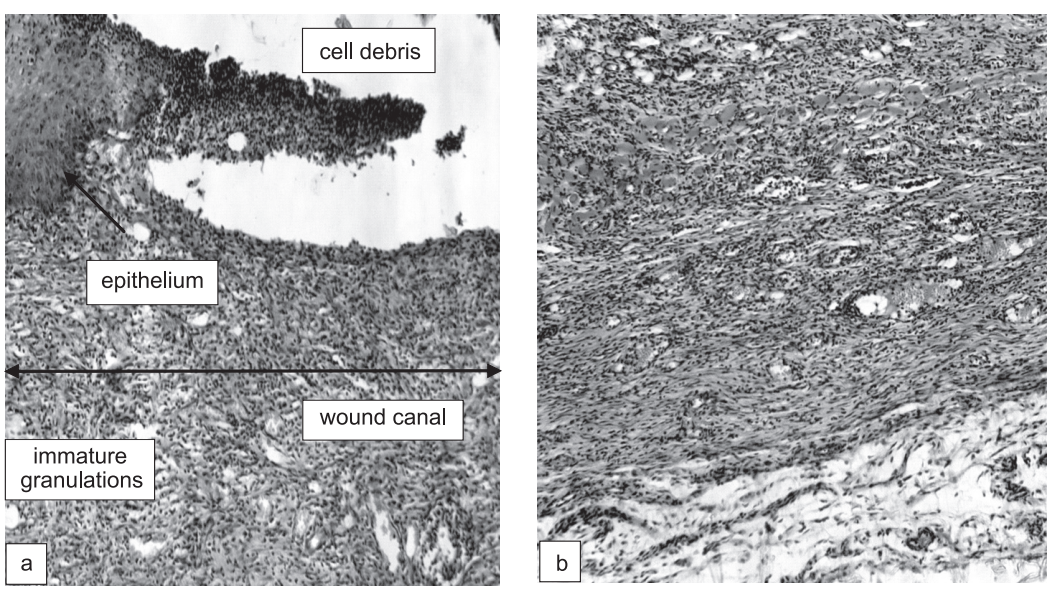

Fig. 10. Stitched-up linear incised wound of rats' skin which was treated with gel "Titriolum": a - the wound is not repaired. There is a quite immature granulation tissue under the remains of crust in the wide wound canal;

$b$-inflammation in muscle plate and subcutaneous tissue. Haematoxylin and eosin. x100

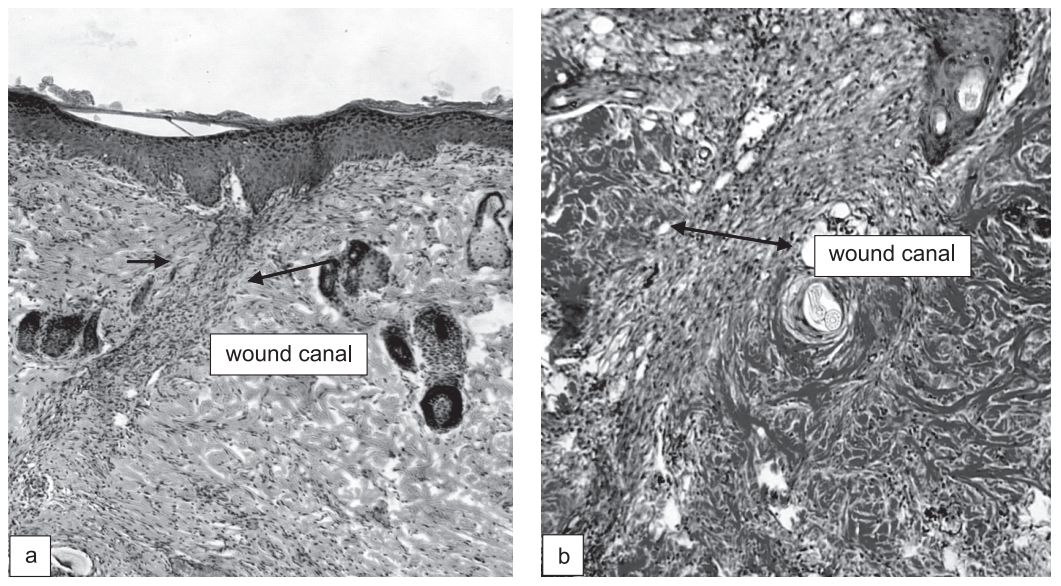

Fig. 11. Stitched-up linear incised wound of rats' skin which was treated with gel "Titriolum": a - obvious decrease of wound canal width (haematoxylin and eosin); $b$ - fibrous type of tissue in it (Picro-fuchsin according to the method of van Gieson). x100

pendages - hair follicles and oil glands - is absent (Fig. 8).

Part of rats had "erosive" skin lesions of different length which touched only epidermis and were observed out of wound area in some areas. Restoration of epithelial sheet under sanioserous-cell debris was not observed. Besides, acanthotic epidermis proliferation near such areas was sometimes very significant (Fig. 9). Symptoms of productive inflammation are often observed in subcutaneous tissue and muscle plate.

Wound of $70 \%$ of rats still rankles, epithelization of surface is incomplete, wound canal ranges from moderate to wide, granulation tissue in it is not mature enough after

Table

\section{SEMI-QUANTITATIVE APPRAISAL OF WOUND CONDITION OF LINEAR INCISED WOUNDS OF RATS' SKIN ON APPLICATION OF CREAM DERMALIPOIN, GRADE, MID-POINT (Q25;Q75), I=6}

\begin{tabular}{|l|c|c|c|}
\hline \multirow{2}{*}{ Group of rats } & \multicolumn{3}{|c|}{ Index } \\
\cline { 2 - 4 } & Wound canal width & $\begin{array}{c}\text { Maturity of newly-formed tissue } \\
\text { in the wound }\end{array}$ & $\begin{array}{c}\text { Completeness of skin restoration } \\
\text { on the spot of former wound }\end{array}$ \\
\hline Control pathology & $3.02 .0 ; 3.0)$ & $2.0(1.0 ; 3.0)$ & $0.0(0.0 ; 1.0)$ \\
\hline Dermalipoin Cream & $0.0(0.0 ; 0.0)^{*} /{ }^{* *} / * *$ & $4.0(3.0 ; 4.0)^{* * *} / /^{* * *}$ & $3.0(3.0 ; 3.0)^{* * *} / /^{* * *}$ \\
\hline Carboderm Cream & $2.5(2.0 ; 3.0)$ & $2.0(1.0 ; 3.0)$ & $0.5(0.0 ; 1.0)$ \\
\hline Titriolum Gel & $1.5(1.0 ; 3.0)$ & $2.5(2.0 ; 3.0)$ & $0.5(0.0 ; 1.0)$ \\
\hline
\end{tabular}

Note: * - statistically significant differences in respect of group of control pathology (Mann-Whitney method, $\mathrm{p}>0.05$ ); ${ }^{* *}$ - statistically significant differences in respect of group of animals which were treated with comparator drug cream "Carboderm" (Mann-Whitney method, $\mathrm{p}>0.05$ ): *** - statistically significant differences in respect of group of animals which were treated with comparator drug gel "Titriolum" (Mann-Whitney method, $\mathrm{p}>0.05$ ) 
application of gel "Titriolum". There are significant symptoms of productive inflammation in muscle plate and subcutaneous tissue (Fig. 10). Complete wound repair, obvious decrease of wound canal width, transformation of granulation tissue into fibrous tissue with a certain degree of restoration were observed on the skin of $30 \%$ of animals (Fig. 11).

As reflected by microscopic results, microscopic view of stitched-up linear incised wound, made on rats of different groups of experiment, even within the bounds of one group, was slightly different. So, for added convenience of comparison according to selected scale and parameters, semi-quantitative (point-based) appraisal of wound condition was carried out. Results are included in the Table.

After application of cream "Dermalipoin", all indexes were authentically improved in comparison with control pathology which is an anatomic proof of better strength of tissue in the area of former wound. Experimental cream had authentic advantage upon these indexes and over comparator drugs cream "Carboderm" and gel "Titriolum".

\section{CONCLUSIONS}

On the model of linear incised wounds of rats, cream "Dermalipoin" shows a clear reparative action which is demonstrated in wound repair process acceleration in comparison with control pathology and decrease of intensity of cytodestuctive processes.

\section{REFERENCES}

1. Абаев Ю. К. Справочник хирурга. Раны и раневая инфекция / Ю. К. Абаев. - Ростов н/Д: Феникс, 2006. - 427 с.

2. Зайцев В. М. Прикладная медицинская статистика / В. М. Зайцев, В. Г. Лифляндский, В. И. Маринкин. - С.Пб.: ФОЛИАНТ, 2003. - 429 с.

3. Кушкун А. А. Руководство по лабораторным методам диагностики / А. А. Кушкун. - М.: ГЭОТАРМедиа, 2007. - 800 с.

4. Лапач С. Н. Статистические методы в медикобиологических исследованиях с использованием Excel / С. Н. Лапач, А. В. Чубенко, П. Н. Бабич. 2-е изд., перераб. и доп. - К.: МОРИОН, 2001. - 408 с.

5. Нагайчук В. І. Сучасні підходи до надання допомоги хворим з опіками / В. І. Нагайчук // Мистецтво лікування. - 2010. - № 5. - С. 24-27.

6. Пирс Э. Гистохимия теоретическая и прикладная / Пер. с англ. - М.: Изд-во иностран. лит. - 1962. - 962 с.

7. Соколовский В. В. Гистохимические исследования в токсикологии / В. В. Соколовский. - Л.: Медицина, 1971. - $176 \mathrm{c}$.

8. Яковлєва Л. В. Експериментальне вивчення нових препаратів для місцевого лікування ран: [метод. рекоменд.] / [Л. В. Яковлєва, О. В. Ткачова, Я. О. Бутко та ін.]. - Х.: Вид-во НФаУ, 2013. - 52 с. 
УДК 615.454.1:616-001.4:-001.17:616-003.9:616-08:612.398.193:665.327.2|.3

Н. Н. Кононенко, А. М. Шейхали ИССЛЕДОВАНИЕ РЕПАРАТИВНЫХ СВОЙСТВ НОВОГО КОМБИНИРОВАННОГО КРЕМА ДЕРМАЛИПОИН НА МОДЕЛИ ЛИНЕЙНЫХ РЕЗАНЫХ РАН

Для местного лечения воспалительных заболеваний кожи перспективными являются лекарственные средства растительного происхождения. Новый комбинированный препарат в форме крема для лечения воспалительных и микробных заболеваний кожи условно назван «Дермалипоин» и в его состав входят: $\alpha$-липоевая кислота, мочевина, оливковое масло, масло чайного дерева. ПЕГ-400 изучали на модели скипидарного дерматита у крыс. Эффективность крема оценивали по общему количеству лейкоцитов, лейкоцитарному составу периферической крови, толщине кожной складки и по состоянию кожи. На основании наших исследований было показано, что крем «Дермалипоин» обладает выраженным противовоспалительным эффектом и является более активным препаратом по сравнению с мазью «Фладекс».

Ключевые слова: $\alpha$-липоевая кислота; мочевина; оливковое масло; масло чайного дерева; ПЕГ-400, скипидарный дерматит

\section{УДК 615.454.1:616-001.4:-001.17:616-003.9:616-08:612.398.193:665.327.2|.3 \\ Н. М. Кононенко, А. М. Шейхалі ДОСЛІДЖЕННЯ РЕПАРАТИВНИХ ВЛАСТИВОСТЕЙ НОВОГО КОМБІНОВАНОГО КРЕМУ ДЕРМАЛІПОЇН НА МОДЕЛІ ЛІНІЙНИХ РІЗАНИХ РАН}

У зовнішньому лікуванні запальних захворювань шкіри перспективними є лікарські засоби рослинного походження. Новий комбінований препарат у формі крему для лікування запальних і мікробних захворювань шкіри умовно названий «Дермаліпоїн» і до його складу увійшли: $\alpha$-ліпоєва кислота, сечовина, оливкова олія, олія чайного дерева. ПЕГ-400 вивчали на моделі скипидарного дерматиту у щурів. Ефективність крему «Дермаліпоїн» оцінювали за загальною кількістю лейкоцитів, лейкоцитарним складом периферичної крові, товщиною шкірної складки та станом шкіри. На основі проведенного дослідження було показано, що крем «Дермаліпоїн» чинить виражений протизапальний ефект і $є$ більш активним препаратом порівняно 3 маззю «Фладекс».

Ключові слова: $\alpha$-ліпоєва кислота; сечовина; оливкова олія; олія чайного дерева; ПЕГ-400; скипидарний дерматит

Адреса для листування:

61002, м. Харків, вул. Куликівська, 12.

Національний фармацевтичний університет
Надійшла до редакції 20.10.2016 р. 